\title{
The Gulf Cooperation Council
}


The ASEAN Studies Centre of the Institute of Southeast Asian Studies in Singapore is devoted to working on issues that pertain to the Association of Southeast Asian Nations as an institution and a process, as distinct from the broader concerns of the Institute with respect to Southeast Asia.

Through research, conferences, consultations, and publications, the Centre seeks to illuminate ways of promoting ASEAN's purposes - political solidarity, economic integration and regional cooperation - and the obstacles on the path to achieving them. Through its studies, the Centre offers a measure of intellectual support to the ASEAN member-countries and the ASEAN Secretariat in building the ASEAN Community, with its political/security, economic and socio-cultural pillars. The Centre aims to conduct studies and make policy recommendations on issues and events that call for collective ASEAN actions and responses.

The Centre seeks to work together with other intellectual centres, institutes, think-tanks, foundations, universities, international and regional organizations, government agencies, and non-governmental organizations that have similar interests and objectives, as well as with individual scholars and the ASEAN Secretariat.

The Institute of Southeast Asian Studies (ISEAS) was established as an autonomous organization in 1968. It is a regional centre dedicated to the study of socio-political, security and economic trends and developments in Southeast Asia and its wider geostrategic and economic environment. The Institute's research programmes are the Regional Economic Studies (RES, including ASEAN and APEC), Regional Strategic and Political Studies (RSPS), and Regional Social and Cultural Studies (RSCS).

ISEAS Publishing, an established academic press, has issued more than 2,000 books and journals. It is the largest scholarly publisher of research about Southeast Asia from within the region. ISEAS Publishing works with many other academic and trade publishers and distributors to disseminate important research and analyses from and about Southeast Asia to the rest of the world. 


\section{ASEAN Studies Centre Institute of Southeast Asian Studies}

Report No. 12

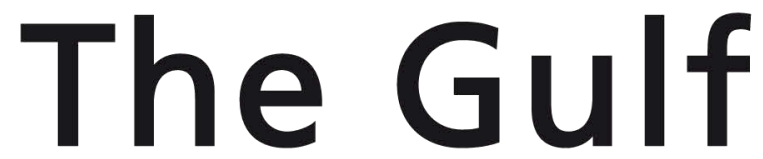

Cooperation

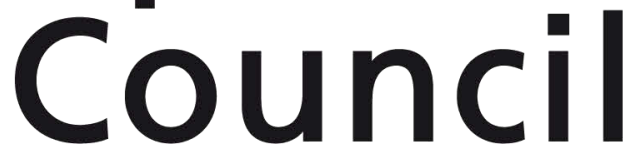

A Rising Power and Lessons for ASEAN

LINDA LOW | LORRAINE CARLOS SALAZAR

\section{누바노}

INSTITUTE OF SOUTHEAST ASIAN STUDIES

Singapore 
First published in Singapore in 2011 by

ISEAS Publishing

Institute of Southeast Asian Studies

30 Heng Mui Keng Terrace

Pasir Panjang

Singapore 119614

E-mail: publish@iseas.edu.sg

Website: bookshop.iseas.edu.sg

All rights reserved. No part of this publication may be reproduced, stored in a retrieval system, or transmitted in any form or by any means, electronic, mechanical, photocopying, recording or otherwise, without the prior permission of the Institute of Southeast Asian Studies.

(C) 2011 Institute of Southeast Asian Studies, Singapore

The responsibility for facts and opinions in this publication rests exclusively with the authors and their interpretations do not necessarily reflect the views or the policy of the publisher or its supporters.

\section{ISEAS Library Cataloguing-in-Publication Data}

Low, Linda.

The Gulf Cooperation Council : a rising power and lessons for ASEAN / Linda Low and Lorraine Carlos Salazar.

1. Gulf Cooperation Council.

2. Persian Gulf Region-Economic integration.

I. Salazar, Lorraine Carlos.

II. Title.

HC415.15 L91

ISBN 978-981-4311-40-3 (soft cover) ISBN 978-981-4311-41-0 (e-book PDF)

Typeset by Superskill Graphics Pte Ltd

Printed in Singapore by 